Edyta Dołęowska, Katarzyna Klibisz, Anna Tworkowska

Uniwersytet w Biatymstoku

\title{
CYWILNOPRAWNA REGULACJA PRAWA DO GROBU
}

Śmierć stanowi zjawisko nieuniknione, a sposób obchodzenia się ze zwłokami jest wyrazem rozwoju społeczeństwa i poziomu, na jakim się ono aktualnie znajduje. Na przestrzeni wieków, w tradycji funeralnej ukształtował się zwyczaj chowania zmarłych w ziemi. W tym celu potrzebne było wyznaczenie odpowiednich terenów - cmentarzy, które z jednej strony miały zapewnić ludności ochronę sanitarną, z drugiej zaś szacunek zarówno dla samego zmarłego, jak i jego rodziny. Nazwa cmentarz pochodzi od greckiego słowa koimeterion, oznaczającego miejsce spoczynku, snu. Jednakże by do takiego pochówku mogło dojść, potrzebne było ukształtowanie się konstrukcji prawnej, tzw. prawa do grobu.

\section{Status cmentarzy wg uregulowań ustawy o cmentarzach i chowaniu zmarłych}

W Polsce regulacje dotyczące m.in. zakładania i utrzymania cmentarzy zawarte są w ustawie z dnia 31 stycznia 1959 r., o cmentarzach i chowaniu zmarłych. ${ }^{1}$ Według ustawowych ustaleń cmentarze stanowią publicznoprawne zakłady użyteczności publicznej o szczególnym charakterze i nie posiadają osobowości prawnej. Ustawa nie zawiera definicji cmentarza, ustawodawca określił jednak, że jest to teren przewidziany $\mathrm{w}$ miejscowym planie zagospodarowania przestrzennego na chowanie zmarłych (art. 3). Cmentarze mają być przy tym utrzymane jako tereny zielone o założeniu parkowym, na których zieleń podlega ochronie przed zniszczeniem. ${ }^{2}$

Cmentarze zakładane mogą być przez organy samorządu terytorialnego oraz władze kościołów i związków wyznaniowych (art. 1, ust. 2-3 ustawy o cmentarzach). Cmentarze komunalne utrzymywane i zarządzane są przez właściwe ze względu na położenie nekropolii zarządy gmin lub miast. Cmentarze wyznaniowe

Ustawa z dnia 31 stycznia 1959 r., o cmentarzach i chowaniu zmarłych, Dz.U. Nr 11, poz. 62.

Rozporządzenie Ministra Gospodarki Komunalnej z dnia 25 sierpnia 1959 r., w sprawie określenia, jakie tereny pod względem sanitarnym są odpowiednie na cmentarze, Dz.U. z 1959 r. Nr 52, poz. 315. 
stanowią zaś cmentarze zakładane przez właściwe władze kościelne. Zarząd cmentarzami wyznaniowymi, wedle regulacji przewidzianej w Polsce, spoczywa w rękach właściwych kościołów, związków religijnych oraz żydowskich gmin wyznaniowych. ${ }^{3} \mathrm{~W}$ regulacji dotyczącej cmentarzy wyznaniowych ważnym jest, że mimo iż przeznaczone są do chowania osób o określonym wyznaniu, istnieje obowiązek przyjęcia do pochowania na nim osób innego wyznania i niewierzących, o ile w danej miejscowości cmentarz ten jest jedynym istniejącym. Forma takiego pochówku nie może zawierać żadnych elementów dyskryminacji (art. 8, ust. 2 i 5 ustawy o cmentarzach). Rodzaj cmentarza nie ma wpływu na zakres stosowania przepisów bezwzględnie obowiązujących. Zastosowanie znajdują więc wszystkie przepisy zawarte w ustawie o cmentarzach i w wydanych do niej rozporządzeniach wykonawczych.

W momencie, kiedy wszystkie miejsca grzebalne danego cmentarza są zajęte i nie ma możliwości ponownego pochówku na istniejącym już grobie, cmentarz ulega zamknięciu. Decyzję o zamknięciu cmentarza komunalnego podejmuje właściwa rada gminy lub miasta. Użycie danego terenu na inny cel możliwe jest po upływie 40 lat od dnia ostatniego pochówku (art. 6, ust. 1 ustawy o cmentarzach). Jeżeli jednak cmentarz wpisany jest na listę zabytków, wykorzystanie jego terenu na inny cel uzależnione jest od uzyskania zgody ministra właściwego do spraw kultury. Decyzję o zamknięciu cmentarza wyznaniowego podejmuje zaś właściwa władza kościelna po zasięgnięciu opinii inspektora sanitarnego. Również i w tym wypadku do ponownego wykorzystania terenu niezbędny jest upływ 40 lat od ostatniego pochówku oraz dodatkowo zgoda właściwej władzy kościoła lub związku wyznaniowego. Jeżeli jednak teren cmentarza był kościołowi lub związkowi wyznaniowemu oddany jedynie w użytkowanie wieczyste, ich zgoda nie jest konieczna.

Będące przedmiotem późniejszej analizy groby ludzkie usytuowane mogą być jedynie na cmentarzach. Sądy niejednokrotnie przedstawiały stanowisko, w myśl którego za niedopuszczalne uznawały grzebanie zmarłych na prywatnych posesjach. ${ }^{4}$

Na terenie cmentarzy powstać mogą cztery rodzaje grobów. Ich precyzyjne określenie jest niezbędne z uwagi na fakt, że rzutuje ono na późniejszy zakres tzw. prawa do grobu. Wyróżnić można groby ziemne, murowane, rodzinne oraz katakumby.

Występujące najczęściej prawo do grobu ziemnego przysługuje uprawnionym przez okres 20 lat. Po ich upływie bliscy tracą roszczenie o przywrócenie prawa do grobu, choćby stale go odwiedzali i utrzymywali $\mathrm{w}$ należytym porządku. ${ }^{5} \mathrm{~W}$ takim

A. Wedeł-Domaradzka, Śmierć a prawa człowieka, Toruń 2010, s. 210.

Wyrok NSA - Ośrodek Zamiejscowy w Katowicach z dnia 19 V 1997 r., SA/Ka 1717/95.

Uchwała SN - Izba Cywilna z dnia 29 III 1977 r., III CZP $17 / 77$. 
przypadku zarządza się przeniesienie szczątków poprzednio pochowanych zwłok na inne miejsce tego samego cmentarza, w tym także poza jego powierzchnię grzebalną, chyba że osoba uprawniona do pochowania zwłok wyrazi życzenie, aby szczątków nie wydobywać. Za postulat de lege ferenda uznać można nałożenie na zarząd cmentarza obowiązku informowania osób zainteresowanych o zbliżającym się terminie przeniesienia szczątków. ${ }^{6}$

Powyższe regulacje nie mają zastosowania w przypadku grobów murowanych. Prawo do pochowania innej osoby niż ta, która ma prawo do grobu w tym przypadku bowiem w ogóle nie powstaje. Grób murowany nigdy jednak nie stanowi przedmiotu odrębnej od gruntu własności. O pochowaniu zwłok w grobie mającym charakter grobu rodzinnego decydują wspólnie: osoba, która poniosła koszty budowy grobu i uiściła opłatę za korzystanie z miejsca na cmentarzu oraz członkowie najbliższej rodziny. ${ }^{7}$

Cmentarz zawsze traktowany powinien być jako szczególne miejsce przeznaczone do wykonywania kultu pamięci osoby zmarłej. W momencie pochowania w grobie pierwszego zmarłego jego najbliżsi nabywają prawo do stałego odwiedzania grobu. W ten też sposób powstaje swoista wspólność prawa do grobu i to niezależnie od poniesionych przez konkretne osoby kosztów.

\section{Pojęcie prawa do grobu. Prawo do grobu jako dobro oso- biste}

Nie występuje normatywna definicja ,prawa do grobu”. W celu wypełnienia luki prawnej, w orzecznictwie wskazuje się, iż pod tym pojęciem rozumie się różne uprawnienia umożliwiające osobom bliskim sprawowanie kultu pamięci zmarłych. ${ }^{8}$ Uprawnienia te mogą mieć charakter zarówno niemajątkowy, jak i majątkowy, przy czym elementom osobistym przypada rola wiodąca, bez względu na to, jaka jest wartość elementów majątkowych tego prawa i na czym one polegają. ${ }^{9}$ Uprawnienia osobiste odnoszą się do sfery uczuć, z kolei majątkowe związane są z nakładami praktycznymi, co do zasady stanowiącymi ekwiwalent pieniężny. Zatem na treść prawa do grobu składają się elementy osobiste i majątkowe. ${ }^{10}$ Podlegają one ochronie według zasad określonych w przepisach, odpowiednio o ochronie dóbr osobi-

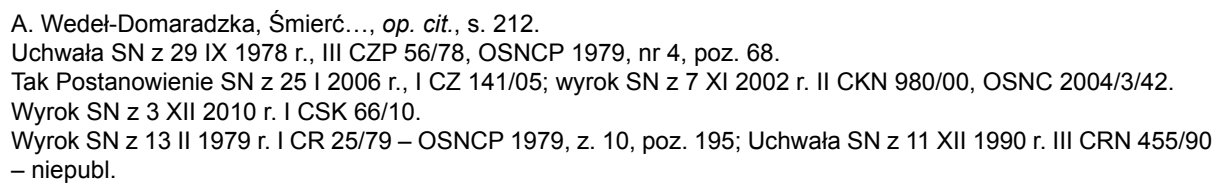


stych albo majątkowych. ${ }^{11}$ Uprawnionymi stają się osoby bliskie, których celem jest sprawowanie kultu pamięci zmarłych.

Kultywowanie pamięci osoby zmarłej stanowi prawo samoistne osób bliskich zmarłego. ${ }^{12} \mathrm{Na}$ treść tego pojęcia składają się prawo do pielęgnowania grobu, ustalenia napisu na nagrobku, ekshumacji zwłok, pochówku, jak również prawo do kultu pamięci o bliskim zmarłym. ${ }^{13}$ Wydaje się, iż kultywowanie pamięci osoby zmarłej stanowi przedłużenie zewnętrznego elementu czci człowieka za życia. ${ }^{14}$

Możliwość sprawowania tak rozumianego kultu pamięci osoby zmarłej stanowi dobro osobiste przysługujące osobie bliskiej zmarłego. W kodeksie cywilnym nie została ukształtowana definicja syntetyczna dóbr osobistych, zatem zasadnym wydaje się odwołanie się do piśmiennictwa. Jak wskazuje Z. Radwański, ${ }^{15}$ dobra osobiste są to pewnego rodzaju uznane przez system prawny wartości obejmujące integralność fizyczną i psychiczną człowieka, jego indywidualność, godność i pozycję w społeczeństwie, stanowiące przesłankę samorealizacji osoby ludzkiej. W podobnym tonie wypowiada się A. Szpunar, ${ }^{16}$ określając dobra osobiste jako wartości o charakterze niemajątkowym, wiążące się z osobowością człowieka, uznane powszechnie w społeczeństwie.

Zakwalifikowanie prawa do grobu jako uprawnienia o charakterze dobra osobistego wynikającego z kultu pamięci osoby zmarłej jest istotne ze względu na stosowanie przepisów stanowiących jego ochronę. Przedmiotem ochrony prawnej jest w tym wypadku prawo do sprawowania kultu osoby zmarłej, natomiast przesłankę tej ochrony stanowi naruszenie dobra osobistego podmiotu tego prawa. ${ }^{17}$ Jeżeli uprawniony powołuje się na naruszenie sfery jego indywidualnych odczuć związanych z kultywowaniem pamięci o osobie zmarłej, zastosowanie znajdują roszczenia przewidziane w art. $24 \S 1$ i 2 k.c. oraz w art. 448 k.c. ${ }^{18}$

Za istotne uznaje się następujące roszczenia:

- roszczenie o zaniechanie działania powodującego zagrożenie, jeżeli działanie to jest bezprawne,

- roszczenie o dopełnienie czynności potrzebnych do usunięcia jego skutków,

11 Tak Postanowienie SN z 25 I 2006 r. I CZ 141/05.

12 Por. wyrok SN z 12 VII 1968 r., I CR 252/68.

13 Wyrok SN z 4 XI 1969 r., II CR 390/69; por. orzeczenie SN z 6 II 2008 r., II CSK 747/04, niepubl.; Wyrok SN z 13 VII 1977 r., I CR 234/77; Orzeczenie SN z 13 I 1965 r., I CR 464/64, OSNCP Nr 10/1965, poz. 171.

14 Por. P. Księżak, [w:] Kodeks cywilny. Komentarz. Część ogólna, M. Pyziak-Szafnicka (red.), Warszawa 2009,

s. 271; por. także: A. Szpunar, Ochrona pamięci osoby zmarłej, Pal. 1984, nr 7-8, s. 8 i n.

Z. Radwański, Prawo cywilne - część ogólna, Warszawa 2007, s. 161.

A. Szpunar, Ochrona dóbr osobistych, Warszawa 1979, s. 106.

Wyrok SN z 3 XII 2010 r. I CSK 66/10.

Tak Postanowienie SN z 25 I 2006 r. I CZ 141/05. 
- roszczenie o zapłatę zadośćuczynienia pieniężnego lub odpowiedniej sumy pieniężnej na wskazany cel społeczny.

Co więcej, należy zwrócić uwagę na powództwo posesoryjne i powództwo ustalające.

\section{Materialnoprawne źródło powstania prawa do grobu}

W rozważaniach nad cywilnoprawnymi aspektami prawa do grobu należy odnieść się przede wszystkim do genezy tego prawa. Sąd Najwyższy stoi na stanowisku, że artykuł 10 ust. 1 ustawy o cmentarzach nie stanowi materialnoprawnego źródła powstania prawa do grobu. ${ }^{19}$ Oznacza to, że źródła tego prawa należy szukać poza tą materią ustawową.

Sama konstrukcja prawa do grobu powstaje na mocy umowy cywilnoprawnej zawartej pomiędzy zarządem cmentarza a osobą uprawnioną do pochowania zwłok. Należy uznać, iż jest to umowa nienazwana, której przedmiotem jest przyjęcie zwłok osoby zmarłej do pochowania. Za przyjęciem takiego stanowiska stoi fakt, iż stosunek powstały w wyniku zawarcia umowy zawiera elementy wielu innych stosunków prawnych, jednocześnie nie mając własnej nazwy, nie funkcjonuje samodzielnie w prawie cywilnym. Ponadto stosunki prawne pomiędzy zarządem cmentarza a osobami uprawnionymi do pochowania zwłok mają charakter cywilnoprawny i charakteryzują się równorzędnością stron. ${ }^{20}$

Ogół wszystkich uprawnień, które przysługują osobie zainteresowanej składa się na prawo do grobu. Podstawowym źródłem tego prawa jest wspomniana umowa cywilnoprawna, kreowana w oparciu o zasadę swobody umów (art. $353^{1}$ k.c.). Uzupełniająco stosuje się przepisy kodeksu cywilnego - zarówno przepisy ogólne dotyczące zobowiązań, jak i odpowiednio poszczególnych umów nazwanych. Umowa ta może być zawarta $\mathrm{w}$ dowolnej formie, nawet w sposób dorozumiany - poprzez przejęcie zwłok do pochowania i uiszczenie opłaty. Treść prawa do grobu czy jego zasięg temporalny uzależnione są od treści umowy i rodzaju grobu, który został w niej wskazany.

Cywilnoprawny charakter tej umowy znajduje swoje oparcie w ugruntowanym już stanowisku judykatury. Sąd Najwyższy w uchwale z 7 grudnia 1970 r. określił stosunek powstały w następstwie zawarcia umowy, mocą której zarząd cmentarza oddaje zainteresowanej osobie miejsce na grób, jako ,swoisty stosunek cywilnoprawny". ${ }^{21}$ Zgodnie z przywołaną uchwałą, w ramach powyższego stosunku

\footnotetext{
19 Wyrok SN z 9 XII 2011 r., III CSK 106/11, nr LEX 1165006; także w wyroku SN z 3 XII 2010 r., I CSK 66/10, nr LEX 738085.

20 Wyrok SA w Warszawie z 11 III 2005 r., I ACa 853/04, nr LEX 179867.

21 Uchwała SN z 7 XII 1970 r. , III CZP 75/70, OSNCP 1971, nr 7-8, poz. 127.
} 
„osoba ta uzyskuje nie tylko prawo do pochowania zmarłego, ale także - zgodnie z powszechnym zwyczajem - szereg uprawnień o charakterze trwałym, takich jak prawo wzniesienia nagrobka i jego przeksztatcenia, prawo do stałego odwiedzania grobu, stałego jego utrzymywania w należytym stanie, prawo wykonywania zmian o charakterze dekoracyjnym itp.” Wymieniony szereg uprawnień, polegających „,na wykonywaniu swoistego władztwa faktycznego nad grobem" odpowiada posiadaniu zależnemu w rozumieniu art. 336 k.c. ${ }^{22}$

Jedną z konsekwencji cywilnoprawnego charakteru umowy o pochowanie zwłok jest brak ograniczeń ustawowych po stronie osoby uprawnionej co do wyboru rodzaju grobu. Do istotnych postanowień umowy o pochowanie zwłok należy przede wszystkim określenie miejsca pochówku, rodzaju grobu (ziemny czy murowany) oraz jego przeznaczenie. Bez wątpienia powyższe essentialia negoti winny znaleźć się w umowie o pochowanie zwłok, a co za tym idzie, każdemu w ramach jego uprawnień przysługuje roszczenie o zawarcie umowy uwzględniającej te treści.

Postanowienia regulaminów wydawanych przez zarządców cmentarzy nie mogą pozostawać w sprzeczności z przepisami ustaw bezwzględnie obowiązujących i ograniczać praw osób uprawnionych do pochowania - tak stwierdził Sąd Apelacyjny w Warszawie w wyroku z dnia 11.03.2005 r. ${ }^{23} \mathrm{~W}$ uzasadnieniu Sąd podkreślił, że w orzecznictwie sądowym dominujący jest pogląd, iż ,stosunki prawne pomiędzy zarzadem cmentarza a osobami uprawnionymi do pochowania zwłok maja charakter cywilnoprawny i charakteryzują się równorzędnościa stron. Przyjęcie zwłok do pochowania, wybór miejsca przeznaczonego na grób oraz wybudowanie grobu sa czynnościami opartymi na cywilnoprawnej umowie, o czym wyraźnie przesadza treść art. 7 ust. 4 ustawy [o cmentarzach]. Dotyczy to bez żadnych różnic tak cmentarzy komunalnych (art. 1 ust. 1 ustawy o cmentarzach), którymi administruje gmina jak i cmentarzy wyznaniowych, którymi zarządzaja kościoły, związki religijne." 24

\section{Problematyka prawa do grobu jako z jednej strony dobra osobistego, z drugiej zaś prawa o charakterze majątkowym}

Wiele kwestii związanych z prawem do grobu jest nieustalonych - prawo to rozpatruje się przede wszystkim w ramach regulacji prawa cywilnego. Brak szczegółowych regulacji pociąga za sobą przede wszystkim powszechny brak świadomości, zarówno użytkowników, jak i administratorów cmentarzy, czym jest i do kogo należy tak powszechne prawo. Należy zwrócić uwagę, że prawo to ma z jednej strony 
charakter dobra osobistego, z drugiej zaś prawa o charakterze majątkowym, a oba te elementy przenikają się wzajemnie. Sąd Najwyższy wielokrotnie podkreślał dwoistość tego prawa. Przykładowo, w wyroku z dnia 14 października 2011 r. Sąd ten stwierdził, iż „w obowiąującym obecnie stanie prawnym nie występuje "prawo do grobu», które mogłoby być rozumiane jako uregulowane przez przepisy prawa cywilnego prawo podmiotowe, obejmujace określona sfere uprawnień. W rzeczywistości to pojęcie obejmuje różne uprawnienia o catkowicie odmiennym charakterze, a mianowicie mające charakter majątkowy lub niemajątkowy. [...] Postużenie się takim pojęciem nie pozwala więc na stwierdzenie, że chodzi o jakiśs samodzielny i jednolity zakres uprawnień, w zwiazku z czym w każdym poszczególnym wypadku niezbędne jest jednoznaczne określenie, jakie konkretne uprawnienia sa objęte tak ogólnie rozumianym prawem do grobu". ${ }^{25}$

Majątkowy charakter prawa do grobu, obok charakteru osobistego, wydaje się być nierozerwalnie związany z istotą tego prawa. Uprawnienie do grobu zawiera elementy o charakterze majątkowym, bowiem zakup miejsca na cmentarzu i urządzenie grobu wymaga świadczeń finansowych, niekiedy bardzo znacznych. Ze względu jednak na dominujący charakter dobra osobistego prawo do grobu nie podlega regułom dziedziczenia. Prawo do pochowania $\mathrm{w}$ danym grobie przysługuje $\mathrm{z}$ reguły określonym osobom, które same grób urządziły lub dla których został on urządzony. Reguły dziedziczenia mogą co najwyżej służyć za posiłkową wskazówkę w wypadkach, gdy miejsca w grobie rodzinnym nie zostały z góry przeznaczone przez osobę, która go urządziła, dla określonych osób bliskich. ${ }^{26}$

Odnosząc się do majątkowego aspektu prawa do grobu, należy podkreślić, że prawo do grobu nie jest jednak ani prawem własności, ani wieczystego użytkowania grobu. Sąd Najwyższy stwierdzając, że prawo do grobu ma charakter zarówno osobisty, jak i majątkowy, uznał, że nie możne być ono traktowane jako prawo wła-

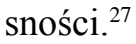

Grób jest nierozerwalnie związany z terenem cmentarza, a jego odłączenie bez naruszenia jego integralności jest $\mathrm{w}$ zasadzie niemożliwe. $\mathrm{Z}$ tego względu należy uznać, że grób stanowić będzie część składową nieruchomości - cmentarza, co wynika z art. 47-48 k.c. Prowadzi to do wniosku, że grób stanowiący część składową nieruchomości, nie może być odrębnym przedmiotem własności ani innych praw rzeczowych.

Jeżeli traktować prawo do grobu jako prawo zawierające elementy o charakterze majątkowym - związane z zakupem miejsca na cmentarzu i urządzeniem grobu,

Wyrok SN z 11 X 2011 r., III CSK 340/10, nr LEX 1095832.

Wyrok SN z 13 ॥I 1979 r., I CR 25/79, nr LEX 2374.

Wyrok SN z 7 VI 2001 r., III CKN 406/00, nr LEX 49475; Uchwała SN z 29 IX 1978 r., III CZP 56/78, OSNCP 1979, nr 4, poz. 68. 
to prawo to konstytuuje się w momencie podpisania - zwykle odpłatnej - umowy o pochowanie zwłok, która, jak wspomniano wyżej, ma charakter cywilnoprawny. Prawo to nie może być jednak przedmiotem ani spadku, ani podziału majątku wspólnego małżonków. Cechy majątkowe tego prawa mają bowiem jedynie charakter uboczny.

Tylko w jednym przypadku prawo do grobu, w którym nikt nie został jeszcze pochowany, może mieć - jak się przyjmuje w orzecznictwie - charakter wyłącznie majątkowy, a mianowicie wtedy, gdy przysługujące danej osobie uprawnienie do pochowania zwłok wygasło, a nikt inny nie nabył jeszcze w miejsce tej osoby uprawnienia do pochowania zwłok w tym grobie. ${ }^{28}$ Wówczas prawa tego nie obejmuje ustawowy zakaz zbywalności ani wyłączenia z dziedziczenia. ${ }^{29}$ Przyjmuje się wprawdzie, iż prawo do grobu murowanego przypomina prawo użytkowania wieczystego, ponadto analogicznie do tego prawa jest ustalane na 99 lat. Okres ten przedłuża się o kolejne 99 lat przy każdym pochówku w tym grobie. Sąd Najwyższy uważa jednak, iż prawo do grobu murowanego w żadnym przypadku nie jest prawem wieczystego użytkowania. Grobowiec ze względu na swoją konstrukcję jest trwale połączony z gruntem, a zatem jest częścią składową gruntu. W przypadku grobów ziemnych prawo to zbliżone jest do dzierżawy i wymaga odnowienia co 20 lat poprzez wniesienie opłaty.

Kolejnym aspektem, przemawiającym za nadaniem prawu do grobu charakteru majątkowego, jest jego skuteczność wobec osób trzecich. Osoby te nie mogą bowiem ingerować w sferę tego prawa, stąd prawo do grobu ma pewne cechy zbliżone do służebności. Sąd Najwyższy w przywoływanej już uchwale z dnia 7 grudnia 1970 r. uznał prawo do grobu za swoiste ,władztwo faktyczne nad grobem, przy czym władztwo to odpowiada treści określonego prawa cywilnego, władztwo to stanowić będzie posiadanie zależne". ${ }^{30} \mathrm{O}$ treści tego uprawnienia była już mowa w kontekście genezy prawa do grobu.

Należy jednak wyraźnie podkreślić, iż ocenianie prawa do grobu w kontekście prawa o charakterze majątkowym doznaje swoich ograniczeń. Tytułem przykładu, w przypadku kiedy w grobie spoczywają już zwłoki określonej osoby uprawnionej do pochowania, to na skutek pochówku następuje zdominowanie uprawnień niemajątkowych i w związku z tym dopuszczalność rozporządzenia prawem do grobu wygasa. ${ }^{31} \mathrm{Z}$ tą chwilą niemożliwe staje się rozdzielenie uprawnień majątkowych od osobistych i z tego względu prawa majątkowe tracą swoją odrębność w tym sensie, że nie mogą być przedmiotem wyłącznego korzystania i rozporządzania ze strony dotychczasowego ich podmiotu. Znajduje to swoje uzasadnienie w istnieniu praw

Uchwała SN z 2 XII 1994 r., III CZP 155/94, OSNC 1995, nr 3, poz. 52. Wyrok SN z 9 XII 2011 r., III CSK 106/11, nr LEX 1165006.

Uchwała SN z 7 XII 1970 r., III CZP 75/70, OSNCP 1971, nr 7-8, poz. 127. Ibidem. 
do grobu przysługujących pozostałym uprawnionym, których źródłem jest fakt powiązań rodzinnych z osobą pochowaną $\mathrm{w}$ grobie. ${ }^{32}$

$\mathrm{Na}$ zakończenie tej części rozważań należy odnieść się do cywilnoprawnej ochrony roszczeń z tytułu prawa do grobu, jako prawa majątkowego sui generis. Znajdują one swą podstawę w przepisach ustawy o cmentarzach, które to prawo przewidują i bliżej regulują. $\mathrm{O}$ tym, jakie roszczenia mające chronić określone prawo przysługują uprawnionemu, $\mathrm{w}$ razie naruszenia tego prawa decyduje - jeżeli ustawa (tak jak np. co do prawa własności - art. 222 i nast. k.c.) kwestii tej nie reguluje w sposób odrębny - treść tego prawa. ${ }^{33}$

\section{Podsumowanie}

Treść prawa do grobu określają zarówno elementy osobiste, jak i majątkowe, które w zależności od konkretnej sytuacji podlegają ochronie według zasad przewidzianych w przepisach o ochronie dóbr osobistych albo na podstawie przepisów dotyczących praw majątkowych. Według orzecznictwa SN z chwilą pochowania w grobie zwłok ludzkich na plan pierwszy wysuwa się aspekt niemajątkowy tego prawa. Elementom osobistym przypada rola decydująca i to niezależnie od tego, jaka jest wartość elementów majątkowych tego prawa i na czym one polegają. Powstają samodzielne i niezależne od siebie prawa każdej osoby bliskiej zmarłego do kultywowania jego pamięci.

Problem z ustaleniem charakteru prawa do grobu polega przede wszystkim na tym, że jako stosunek powstały w wyniku zawarcia umowy zawiera elementy wielu innych stosunków prawnych, jednocześnie nie stanowiąc odrębnej, samodzielnej i wyraźnie nazwanej instytucji prawa. Swoistość stosunku cywilnoprawnego, jakim jest prawo do grobu, polega przede wszystkim na przenikaniu praw majątkowych i osobistych, z których te ostatnie mają zazwyczaj charakter dominujący, co decyduje o bezwzględnym i nietypowym charakterze wynikającego zeń prawa podmiotowego.

Podsumowując uznać można, że całokształt uprawnień wchodzących w skład prawa do grobu, nazwanego przez SN swoistym władztwem faktycznym obejmuje m.in. uprawnienie do użycia grobu w celu pochowania w nim zmarłego, prawo wybudowania i urządzenia grobu, wzniesienia nagrobka, odbywania ceremonii religijnych, kontemplacji czy prawa do stałego odwiedzania grobu i utrzymania go w należytym stanie. 


\section{BIBLIOGRAFIA}

1. Księżak P., [w:] Kodeks cywilny. Komentarz. Część ogólna, Pyziak-Szafnicka M. (red.), Warszawa 2009.

2. Radwański Z., Prawo cywilne - część ogólna, Warszawa 2007.

3. Szpunar A., Ochrona dóbr osobistych, Warszawa 1979.

4. Szpunar A., Ochrona pamięci osoby zmarłej, Pal. 1984, nr 7-8.

5. Wedeł-Domaradzka A., Śmierć a prawa człowieka, Toruń 2010.

6. Ustawa z dnia 31 stycznia 1959 r., o cmentarzach i chowaniu zmarłych, Dz.U. Nr 11, poz. 62.

7. Rozporządzenie Ministra Gospodarki Komunalnej z dnia 25 sierpnia 1959 r., w sprawie określenia, jakie tereny pod względem sanitarnym są odpowiednie na cmentarze, Dz.U. z 1959 r. Nr 52 , poz. 315 .

8. Orzeczenie SN z 13 I 1965 r., I CR 464/64, OSNCP 1965, nr 10, poz. 171.

9. Orzeczenie SN z 6 II 2008 r., II CSK 747/04, niepubl.

10. Postanowienie SN z 25 I 2006 r., I CZ 141/05.,

11. Uchwała SN z 7 XII 1970 r., III CZP 75/70, OSNCP 1971, nr 7-8, poz. 127.

12. Uchwała SN - Izba Cywilna z dnia 29 III 1977 r., III CZP 17/77.

13. Uchwała SN z 29 IX 1978 r., III CZP 56/78, OSNCP 1979, nr 4, poz. 68.

14. Uchwała SN z 11 XII 1990 r., III CRN 455/90 - nie publ.

15. Uchwała SN z 2 XII 1994 r., III CZP 155/94, OSNC 1995, nr 3, poz. 52.

16. Wyrok SN z 12 VII 1968 r., I CR 252/68.

17. Wyrok SN z 4 XI 1969 r., II CR 390/69.

18. Wyrok SN z 13 VII 1977 r., I CR 234/77.

19. Wyrok SN z 13 II 1979 r., I CR 25/79 - OSNCP 1979, z. 10, poz. 195.

20. Wyrok SN z 4 VI 1982 r., I CR 141/82, nr LEX 2819.

21. Wyrok SN z 7 VI 2001 r., III CKN 406/00, nr LEX 49475.

22. Wyrok SN z 7 XI 2002 r., II CKN 980/00, OSNC 2004/3/42.

23. Wyrok SN z 3 XII 2010 r., I CSK 66/10.

24. Wyrok SN z 11 X 2011 r., III CSK 340/10, nr LEX 1095832

25. Wyrok SN z 9 XII 2011 r., III CSK 106/11, nr LEX 1165006.

26. Wyrok SA w Warszawie z 11 III 2005r., I ACa 853/04, nr LEX 179867.

27. Wyrok NSA - Ośrodek Zamiejscowy w Katowicach z dnia 19 V 1997 r., SA/Ka 1717/95. 


\section{THE RIGHT TO A GRAVE UNDER REGULATIONS OF THE CIVIL LAW}

Burying deceased in the ground is today's habit. The necessity to form legal structure was however needed to make such burial. This legal structure is called "the right to a grave". The content of "the right to a grave" includes personal elements and property aspects. Depending on the specific situation, they are protected by the principles laid down in the regulations on the protection of personal rights or the laws concerning property rights. Institution of "the right to a grave" creates doubts in relation to the agreement which forms part of the obligatory establishment of this law. The contract mentioned above contains elements of many other legal relations while not constituting a separate, independent and clearly named legal institutions. The specificity of the civil law relationship as "the right to a grave" lies primarily in the infiltration of personal and property rights, of which the latter are usually dominant, which determine the absolute and the unusual nature of the subjective rights arising from it.

Key words: the right to a grave, the tomb, personal interests. 